\title{
PERSEPSI MASYARAKAT MANDAILING NATAL TENTANG PEMBERANGKATAN PENGANTIN YANG MEMAKAI PAKAIAN HAJI MENURUT HUKUM ISLAM
}

\author{
Misbah Mrd \\ Fakultas Syariah dan Ilmu Hukum, Institut Agama Islam Negeri \\ Padangsidimpuan, Indonesia \\ Email: misbahmardia4@gmail.com \\ Sawaluddin Siregar \\ Fakultas Syariah dan Ilmu Hukum. Institut Agama Islam Negeri \\ Padangsidimpuan, Indonesia \\ Email: lisyasiregar@gmail.com
}

\begin{abstract}
ABSTRAK
Penelitian ini dilatarbelakangi oleh kebiasaan masyarakat Mandailing Natal tentang keberangkatan pengantin wanita ke rumah pengantin pria, dalam hal ini keberangkatan pengantin pria dan wanita selalu memakai baju haji. Penelitian ini juga untuk mengetahui bagaimana persepsi masyarakat Mandailing Natal tentang keberangkatan calon pengantin yang memakai baju haji menurut syariat Islam. Penelitian ini tergolong penelitian lapangan, yang menggunakan beberapa model pengumpulan data, antara lain observasi, wawancara mendalam dan metode dokumentasi. Melihat dari beberapa persepsi Masyarakat Mandailing Natal tentang pakaian haji yang dikenakan oleh kedua mempelai hanya sebagai doa untuk kebaikan kedua mempelai dalam rumah tangga, salah satu persepsi yang diungkapkan oleh masyarakat Mandailing Natal, yaitu: 1) Pakaian haji adalah sebagai salat, agar pengantin baru ini mendapat rezeki untuk datang ke baitullah (Mekah) untuk menunaikan ibadah haji; 2) Pakaian haji dijadikan sebagai doa sebagai upaya keluarga sakinah mawaddah warohmah; 3) Jubah putih yang dikenakan oleh mempelai wanita adalah sebagai kesucian, kebersihan dan kesucian; dan 4) Busana haji merupakan lambang persatuan ummat Islam. Persepsi-persepsi tersebut untuk membangun kemaslahatan bagi masyarakat Mandailing Natal dan tidak melanggar syariat Islam sama sekali, tidak juga mengikis adat-istiadat pengantin di Mandailing, tetapi untuk memajukan nilainilai Islam di masyarakat itu sendiri.
\end{abstract}

Kata kunci: Pakaian Haji; Perkawinan; Hukum Islam. 


\section{PENDAHULUAN}

Syariat Islam yang pertama kali diturunkan adalah pernikahan, di mana belum diturunkannya syariat sholat, puasa, zakat dan haji tapi syariat pernikahan sudah ada sejak dalam surga lantas siapa yang pertama kali menikah? Jawabannya yaitu nabi Adam As. Dengan siti hawa pada waktu itu belum disyariatkan sholat, puasa, zakat dan haji akan tetapi sudah ada pernikahan yang mana Allah Swt. menikahkan keduanya dan malaikat jibril yang menjadi saksi atas pernikahan nabi Adam a.s. Dengan siti hawa, sejarah tersebut menjadi dasar bahwa pernikahan merupakan syariat Syariat pertama (mutaqoddimatun).

Perkawinan sebagai perbuatan hukum antara suami dan isteri, bukan saja bermakna untuk merealisasikan ibadah kepada-Nya, tetapi sekaligus menimbulkan akibat hukum keperdataan di antara keduanya. Namun demikian, karena tujuan perkawinan yang begitu mulia, yaitu membina keluarga bahagia, kekal, abadi berdasarkan Ketuhanan Yang Maha Esa, maka perlu diatur hak dan kewajiban suami dan isteri masing-masing. Apabila hak dan kewajiban masingmasing suami dan isteri terpenuhi, maka dambaan suami isteri dalam bahtera rumah tangganya akan dapat terwujud, didasari rasa cinta dan kasih sayang .

Tradisi perkawinan di Indonesia sangat banyak jumlahnya. Dari satu suku bangsa saja, bisa dijumpai beberapa tradisi upacara perkawinan yang berbeda. Hal ini akan mempengaruhi bentuk riasan dan busana pengantinnya. akan tetapi dari tradisi - tradisi yang ada, tidak banyak yang dikenal masyarakat. Beberapa daerah tertentu mempunyai busana pengantin yang sangat populer karena sering menjadi pilihan orang. Sebut saja busana pengantin dari Jawa, Sunda, atau Padang. Akan tetapi busana pengantin yang ada di Nusantara tidak hanya ada di sekitar Jawa dan Sumatera saja (Rofiq, 2000).

Pakaian atau busana merupakan kebutuhan untuk menutupi bagian tubuh manusia, untuk mempercantik atau ada juga perwujudan refleksi dari suatu budaya termasuk pakaian pernikahan Mandailing. Ketika melangsungkan pernikahan masyarakat Mandailing Natal mewajibkan pakain haji untuk pengantin yang ingin berangkat kerumah mertuanya.

Bila diteliti lebih jauh pakaian haji tersebut, ternyata bukan hanya sekedar pelepas kebiasaan masyarakat itu saja, akan tetapi pakaian haji ini memiliki makna maupun pesan-pesan yang mecerminkan nilai tersendiri, bahkan masyarakat Mandailing Natal mempercayai makna yang sudah diyakini selama ini. Dalam hal inilah, peneliti tertarik untuk mengangkat judul ini untuk diteliti lebih lanjut 


\section{METODE PENELITIAN}

Penelitian ini termasuk penelitian field research (penelitian lapangan), yang menggunakan sejumlah model pengumpulan data, antara lain observasi (pengamatan), wawancara mendalam, dan metode dokumentasi (Syamsuddin, 2007). Menentukan jenis penelitian sebelum terjun ke lapangan adalah sangat signifikan, sebab jenis penelitian merupakan payung yang akan di gunakan sebagai dasar utama pelaksanaan riset. Oleh karenanya, penentuan jenis penelitian di dasarkan pada jenis data yang akan di kumpulkan. penelitian ini adalah field research (penelitian lapangan),yang menitik beratkan pada hasil pengumpulan data dari informan pada lokasi penelian (Lexy \& others, 2002).

\section{HASIL DAN PEMBAHASAN}

\section{Pemberangkatan Pengantin yang Memakai Pakaian Haji Menurut Hukum Islam}

Islam mengajarkan agar setiap Muslim yang memiliki kemampuan diwajibkan bepergian ke Tanah Suci sekurang-kurangnya sekali seumur hidup untuk menunaikan ibadah haji, karena hal itu termasuk rukun Islam yang ke-lima. Kata haji berasal dari bahasa arab "جالح" yang berarti datang atau berkunjung. Dalam Islam maknanya "melakukan ibadah haji", yaitu datang ke Baitullah dan melakukan ibadah-ibadah tertentu, dimulai dari berpakaian ihram, lalu berdiam (wuquf) di Arafah, dilanjutkan dengan melontar jumrah di Mina, țawaf, kemudian sa'i, dan di akhiri dengan mencukur rambut (tahallul) (Departemen Agama RI, 2009).

Baju haji yang diyakini oleh masyarakat Mandailing Natal memiliki persepsi yang berbeda, pengantin yang diberangkatkan ke rumah mertuanya harus memakai baju haji karena sebagian masyarakat memiliki keyakinan dan makna yang bagus tentang pakain haji, yaitu: sebagai doa untuk bisa datang ke baitullah (mekkah) untuk beribadah kepada Sang Pencipta untuk melaksanakan ibadah haji. Yang mana kita ketahui Haji adalah salah satu rukum Islam yang kelima (naik haji kebaitullah bagi orang yang sanggup). Selain itu, masyarakat juga menjadikan baju ini sebagai doa untuk terbinanya keluarga sakinah mawaddah warohmah yang diawali dan dibentengi dengan pakaian Islami yang diperuntukkan untuk orang yang sedang berangkat ke baitullah dan melaksanakan ibadah haji (mekkah).

Fiqih juga mengatur tata cara dalam melaksanakan ibadah haji, sebagaimana ketentuan-ketentuan ibadah lainnya. Terdapat syarat-syarat yang harus dipenuhi sebelum menunaikan ibadah haji. Syarat-syarat tersebut menurut 
Jumhur Fuqaha, yaitu: Islam, baligh, berakal sehat, merdeka (bukan hamba sahaya) dan mampu (istitha'ah). Syarat-syarat tersebut disepakati oleh empat mazdhab, kecuali Imam Syafi'I yang mengakatakan syarat wajib haji hanya satu, yaitu, Islam (Arifin, 2018).

Masyarakat berpendapat bahwa ketika selesai ijab dan qabul antara suami isteri maka pernikahan yang dilakukan sudah sah menurut hukum Islam. Yang mana tidak jauh dari peraturan tata cara haji sesuai menurut para jumhur fuqaha ketika berlangsungnya memperangkatan ibadah haji wajib bagi yang beragama Islam, baligh, berakal sehat, merdeka dan mampu. Dalam pemberangkatan pengantin dari rumah orang tua perempuan memiliki keyakinan bahwa baju haji yang dipakai pengantin akan selamanya memeluk dan berpegang teguh kepada agama Islam, dan memiliki akal yang sehat walaupun nantinya banyak cobaan dalam berumah tangga. Baju haji yang diyakini oleh masyarakat Mandailing Natal hanya sebagai doa saja, bukan sebagai peraturan adat.

Memahami haji secara esensial tidak cukup hanya dipahami melalui perspektif fiqih yang menerangkan secara teori dan praktik. Haji juga harus mampu dipahami melalui kacamata normatif dan filosofis dalam Islam. Dalam literatur fiqih, definisi haji secara termenologi adalah mengunjungi Mekkah untuk mengejakan ibadah tawaf, sa'i, wukuf di Arafah dan ibadah lainnya untuk mendapatkan Ridho dari Allah Swt. Menurut Ishak Farid, haji adalah mengunjungi atau ziarah ke suatu tempat yang dipandang mulia dan diangungkan (Farid, 1999). Ibadah haji adalah simbol persatuan ummat Islam, tanpa memandang ras, suku, warna kulit dan kebangsaan, karena dasar persatuan kaum muslimin adalah syari'ah dan aqidah Islam (Khusna, 2018).

Ibadah haji adalah rukun Islam yang kelima dan sebagai simbol persatuan bagi ummat Islam, dalam hal ini masyarakat Mandailing Natal sangat bangga dan termotivasi ketika memakai pakaian baju haji yang dipakaikan kepada pengantin, karena melihat dari pakaian ini selain masyarakat menjadikan pakaian haji sebagai doa untuk pengantin, masyarakat Mandailing Natal juga memiliki keistimewaan, karena sudah bangga memakai simbol baju persatuan ummat Islam. Dan ini menandakan pernikahan mereka dibentengi dengan simbol kepercayaan Islam dan iman.

Kamus Besar Basaha Indonesia mengatakan bahwa perkawinan berasal dari kata "kawin" yang menurut bahasa artinya membentuk keluarga dengan lawan jenis, melakukan hubungan kelamin atau bersetubuh. Perkawinan juga disebut dengan "pernikahan", berasal dari kata nikah yang menurut bahasa, artinya mengumpulkan, saling memasukkan dan digunakan untuk arti bersetubuh (Munawwir, 2002). Istilah nikah berasal dari bahasa Arab, yaitu nikah, adapula 
yang mengatakan perkawinan menurut istilah fiqh dipakai perkataan nikah dan perkataan zawaj (Kamal, 1974). Sedangkan menurut istilah Indonesia adalah perkawinan. Dewasa ini kerap kali dibedakan antara pernikahan dan perkawinan, akan tetapi pada prinsipnya perkawinan dan pernikahan hanya berbeda dalam menarik akar katanya saja (Sudarsono, 2005). Perkawinan adalah sebuah ungkapan tentang akad yang sangat jelas dan terangkum atas rukun-rukun dan syarat-syarat (Al-Syafi'i, n.d.).

Dalam pandangan Al-Qur'an, salah satu tujuan pernikahan adalah untuk menciptakan sakinah, mawaddah dan rahmah antara suami, istri dan anak-anaknya (Ismatulloh, 2019). Hal ini ditegaskan dalam QS. Ar-Rum: 21 bahwa "Dan diantara tanda-tanda (kebesaran)-Nya ialah Dia menciptakan pasangan-pasangan untukmu dari jenismu sendiri, agar kamu cenderung dan merasa tenteram kepadanya, dan Dia menjadikan di antaramu rasa kasih dan sayang. Sungguh, pada yang demikian itu benar-benar terdapat tanda-tanda (kebesaran Allah) bagi kaum yang berpikir."

Tujuan dari ayat di atas adalah tanda-tanda kekuasaan allah untuk menjalin kehidupan bersama antara laki-laki dan perempuan yang diikat oleh sebuah pernikahan, puncak dari saling mencintai tersebut yaitu terjadinya proses pernikahan, setelah sah menjadi suami istri diharapkan mampu membentuk keluarga yang sakinnah, mawaddah wa rohmah. Adapun syarat dan rukun perkawinan dalam Islam, jumhur ulama sepakat bahwa rukun perkawinan terdiri atas: 1) Adanya calon suami dan calon istri yang akan melakukan perkawinan; 2) Adanya wali dari pihak calon pengantin perempuan; 3) Adanya dua orang saksi; dan 4) Sighat akad nikah, yaitu ijab qabul yang diucapkan oleh wali atau wakilnya dari pihak wanita dan dijawab oleh calon suami, sedangkan untuk syarat sahnya perkawinan secara garis besar ada dua, yaitu: 1) Calon mempelai perempuannya halal dikawin oleh laki-laki yang ingin menjadikannya istri; dan 2) Akad nikahnya dihadiri para saksi.

Merujuk kepada syarat dan rukun perkawinan dalam Islam, di Mandailing Natal juga menekankan bahwa perkawinan harus memenuhi syarat dan rukunnya, dalam hal ini wajib adanya calon memplai laki-laki dan perempuan sehingga mudahnya untuk melangsungkan akad, adanya wali dari pihak perempuan (ayah), jika ayah sudah meninggal dunia bisa saudara kandung laki-laki dari pihak memplai perempuan, jika saudara kandung laki-laki tidak ada maka yang menjadi wali baginya adalah pamannya (saudara kandung laki-laki dari pihak ayah) dan seterusnya, dan menghadirkan dua orang saksi ketika akad diberlangsunkan maka terjadilah ijab dan qabul. 
Apabila merujuk kepada kaidah ushul fiqh "al adatul muhakkamah", adat itu bisa dijadikan hukum jika tidak bertentangan dengan hukum Islam, melihat dari tradisi masyarakat Mandailing Natal yang memakai pakaian haji untuk pemberangkatan pengantin tidaklah melanggar hukum Islam. Karena masyarakat Mandailing Natal tidak memberatkan atau mencoreng nama baik hukum Islam itu sendiri, mereka hanya mencontoh busana dari Islam yaitu pakain yang dipakai saat melakukan ibadah haji.

Pakaian yang dipakai untuk menutupi aurat sangatlah indah, selain dia indah pakaian ini juga menandakan kalau Islam memiliki batasan aurat yang sudah ditentukan. Dalam hal ini, masyarakat Mandailing Natal selain memakai pakaian yang indah mereka juga memakai pakaian simbol dari Islam yang diperuntukkan hanya untuk orang yang melakukan ibadah haji saja, tapi masyarakat Mandailing Natal memakai baju haji saat pemberangkatan pengantin menuju rumah mertuanya.

Perkawinan sebagai perbuatan hukum antara suami dan isteri, bukan saja bermakna untuk merealisasikan ibadah kepada-Nya, tetapi sekaligus menimbulkan akibat hukum keperdataan di antara keduanya. Namun demikian, karena tujuan perkawinan yang begitu mulia, yaitu membina keluarga bahagia, kekal, abadi berdasarkan Ketuhanan Yang Maha Esa, maka perlu diatur hak dan kewajiban suami dan isteri masing-masing. Apabila hak dan kewajiban masingmasing suami dan isteri terpenuhi, maka dambaan suami isteri dalam bahtera rumah tangganya akan dapat terwujud, didasari rasa cinta dan kasih sayang (Rofiq, 1997).

Dalam Kompilasi Hukum Islam masalah hak dan kewajiban suami isteri diatur dalam Pasal 77-84, dan pasal 30 Undang-undang Nomor 1 Tahun 1974 dikemukakan bahwa suami isteri memikul kewajiban yang luhur untuk menegakkan rumah tangga yang sakinah, mawaddah dan warahmah yang menjadi sendi dasar dari susunan masyarakat (Manan, 2017).

\section{Persepsi Masyarakat Mandailing Natal tentang Pemberangkatan Pengantin yang Memakai Pakaian Haji}

Pakaian adalah sesuatu yang dikenakan di badan oleh manusia untuk menutupi auratnya. Menurut KBBI (kamus besar bahasa Indonesia); pakaian adalah barang apa yang dipakai (baju, celana, dan sebagainya). Berpakaian menjadi salah satu ciri khas yang membedakan manusia dengan makhluk lainnya selain dari akal dan pikiran. Berpakaian juga akan menjadikan manusia lebih percaya diri dalam menjalankan aktivitas sehari-hari. Manusia pada umumnya mengenakan pakaiannya sesuai dengan latar belakang budaya dan agamanya 
masing-masing. Berdasarkan tersebut, pakaian bisa menjadi simbol agama. Berkaitan dengan mekanisme berpakaian, dari sejak masa klasik hingga era modern sekarang menjadi sebuah pembahasan yang cukup kontroversial di kalangan umat Islam (Hidayat \& Markos, 2019). Perbedaan itu juga terlihat pada pelengkap pakaian yang dikenakan. Salah satunya merupakan baju jubah warna putih.

Masyarakat Mandailing Natal melambangkan jubah warna putih itu dari kesucian, kebersihan dan kemurnian, pernikahan yang dilambangkan kesucian dan kemurnian ini akan menjadi awal baik untuk pengantin yang akan membina keluarga sakinah mawaddah warahmah yang dipenuhi cinta yang suci, bersih dan murni. Selain itu, masyarakat mencontoh dari kisah para nabi yang menceritakan bahwa para nabi dan sahabat atau lelaki Islam pada zaman dulu memakai jubah, dan pakaian khas inilah yang dicontoh masyarakat Mandailing Natal saat pemberangkatan pengantin dari rumah orang tua perempuan, dan khas pakaian jubah adalah salah satu pakaian Islami yang dipakai pada zaman nabi dan sahabat. Jubah warna putih adalah kesan suci yang sering dijumpai dalam Islam yang menggambarkan aspek suci dalam diri dan aspek suci dalam ikatan perkawinan.

Serban ialah kain yang diikat di kepala atau sehelai kain panjang yang digunakan untuk menutup bahagian separuh atas kepala (Al-Mun'im, 1999). Serban ialah istilah yang digunakan di Malaysia yang dianggap suci dan tidak boleh dipijak sewenang-wenangnya. Kebiasaannya dipakai oleh mereka yang baru balik mengerjakan haji.

Ibn 'Abbas (r.a) meriwayatkan, Rasulullah saw. bersabda: "Berserbanlah, nescaya anda akan bertambah sopan santun". Rasulullah saw. memakai dan membuat lilitan serban kepada Sayyidina Ali dan membiarkan ekor serbannya menjulur keluar pada bahagian belakangnya, sebelum mengutus menantu baginda saw. itu ke Khaybar dalam ekspedisi dakwah, sedangkan masyarakat Arab pada masa itu tidak berbuat demikian (Al-Tabrani, n.d.).

Serban yang dipakai pengantin laki-laki adalah salah satu melambangkan kesopanan, pengantin laki-laki yang diberangkatkan dari rumah pengantin perempuan memakai baju jubah warna putih, serban sesuai dengan anjuran yang dilakukan oleh Rasulullah. Unik dan istimewanya di Mandailing Natal, bukan hanya haji yang berhak memakai pakaian itu tapi pengantin di Mandailing Natal juga berhak memakai pakaian tersebut. Jadi cukup jelas, bahwasanya persepsi masyarakat Mandailing Natal menurut penulis tidak ada yang melanggar hukum Islam. Karena pakaian yang dipakai masih menutup aurat dan masih melambangkan kesopanan, keyakinan masyarakat Mandailing Natal tidak 
melangggar agama sama sekali, yang mana kita ketahui serban adalah salah satu tradisi yang dilakukan oleh Rasulullah.

Menurut Quraish Shihab, Islam juga menganjurkan perempuan menutup auratnya dari ujung kaki hingga kepala. Batas aurat seorang perempuan, yaitu hanya muka dan telapak tangan yang terlihat. Ada alasan tersendiri mengapa Allah Swt. menganjurkan seorang perempuan menutup auratnya, yaitu dalam surat Al-Ahzab ayat 59 bahwa "Hendaklah mereka mengulurkan jilbabnya ke seluruh tubuh mereka. Yang demikian itu supaya mereka lebih mudah untuk dikenal, karena itu mereka tidak diganggu. Dan Allah adalah Maha Pengampun lagi Maha Penyayang" (Shihab, 2002).

Mengingat pentingnya peran perempuan di dunia bahwa perempuan adalah sekolah awal bagi anaknya kelak dan cerminan dari kualitas diri suatu negara, di dalam kegiatannyapun menjadi salah satu sarana untuk membumikan jilbab sesuai dengan syari'at Islam. Dan pengantin perempuan yang ada di Mandailing Natal memakai jilbab bahkan pengantin perempuan ini juga memakai pakaian haji, yang diperuntukkan untuk pakain menuju mekkah, saat pengantin perempuan ini diberangkatkan ke rumah mertuanya dia harus memakai baju jubah putih, jilbab yang dihiasi marhamah dan juga kaos kaki. Ikatan perkawinan ini betul-betul harus di dasari pakain Islami.

Bahkan menurut penulis, pakaian haji yang dipakai pengantin saat berangkat kerumah mertuanya sangatlah bagus, karena di adat Mandailing Natal biasanya pengantin perempuan hanya memakai bulang atau jagar-jagar tanpa memakai jilbab. Jadi pembaharuan yang dilakukan masyarakat Mandailing Natal saat pemberangkatan pengantin memiliki peningkatan yang sangat luar biasa, karena awalnya pengantin perempuan ini tidak memakai jilbab saat resepsi awal sampai akhir diberlangsungkan dan sekarang resepsi awal sampai akhir sudah memakai jilbab.

Pakaian haji yang dipakai pengantin ini bukanlah adat Mandailing, tapi perubahan secara berlahan yang dibuat oleh masyarakat itu sendiri. Ketika masyarakat itu meninggalkan adat pakaian pengantin yang biasanya diberlakukan tidaklah menjadi masalah bagi penulis, karena dulu pengantin itu hanya memakai pakain pengantin, bulang atau mahkota berbentuk tanduk bertingkat dan biasanya berlapis warna emas yang biasa dipakai pengantin etnis Mandailing dari Sumatera Utara, serta jagar-jagar (pengantin perempuan masih gadis) tanpa memakai jilbab, dan ini adalah salah satu perkembangan yang sangat luar biasa bagi masyarakat Mandailing Natal. Karena dalam Islam perempuan wajib menutup auratnya dari ujung rambut sampai ujung kaki, hamya wajah dan telapak tangan yang tidak menjadi aurat bagi perempuan, tapi beberapa tokoh adat tidak setuju dengan 
pakain haji yang diberlakukan di Mandailing Natal karena menurut mereka merusak adat Mandailing itu sendiri, karena ada beberapa alasan yang diutarakan tokoh adat. Salah satunya: Pertama, Merusak Persepsi masyarakat lain, karena pakain adat mandailing hanya memakai baju godang, ampu, selendang songket, bobar, bulang dan juga jagar-jagar, bukan pakain haji; dan Kedua, Terkikisnya adat pengantin Mandailing Natal, karena dari raja-raja sudah diberlakukan pakain pengantin, baju godang, ampu, selendang songket, bobar, bulang ataupun jagarjagar.

Adat pernikahan Mandailing Natal biasanya memakai mahkota yang sudah ditetapkan dari zaman raja-raja yang terdahulu, adapun pengantin laki-laki biasanya memakai "ampu" atau penutup kepala pengantin laki-laki yang terbuat dari bahan beludru hitam dengan ornamen warna emas yang memiliki khas dan bentuk yang unik. Pemilihan warna pada ampu juga menyimpang makna filosofi tersendiri, warna hitam pada ampu erat kaitannya dengan fungsi magis, sementara ornamen warna emas mengandung lambang kebesaran dan keagungan orang yang memakainya dan ampu ini biasa dipakai oleh raja-raja Mandailing Natal.

Adapun pakaian pengantin laki-laki biasanya memakai baju godang (baju yang berbentuk jas tutup terbuat dari kain beludru berwarna hitam). Baju godang yang dipakai pengantin laki-laki ini biasanya berwarna hitam akan tetapi sekarang sudah banyak memiliki variasi yang dibuat oleh masyaraklat itu sendiri, ada warna merah, kuning, hijau, biru atau sesuai selera pengantinnya, dan ini mengakibatkan terkikisnya adat Mandailing Natal itu sendiri.

Baju godang pengantin laki-laki Mandailing dipadankan dengan kain sesamping yang terbuat dari songket atau tenun yang dikenakan dengan cara dibelitkan dari batas pinggang sampai ke lutut. Penggunaan ikat pinggang warna keemasan atau disebut bobar yang membuat pengantin laki-laki semakin gagah nan berwibawa. Dalam hal ini, sebagian masyarakat sudah tidak mengikuti tradisi adat Mandailing bahkan pengatin laki-laki yang sekarang sudah biasa memakai kemeja dan jas hitam saja. Dan kasus inilah yang membuat tokoh adat terkadang tidak setuju dengan perubahan yang dibuat oleh masyarakat karena menyebabkan terkikisnya adat Mandailing Natal. Aksesoris yang diapakai pengantin perempuan Mandailing, memakai dua lembar selendang yang disilangkan pada bagian dada sampai ke punggung, memakai bulang dan juga jagar-jagar.

\section{KESIMPULAN}

Berdasarkan paparan dan analisa data yang telah diuraikan di atas dapat disimpulkan sebagai berikut bahwa baju haji yang dipakai pengantin ketika diberangkatkan ke rumah pengantin laki-laki bukanlah sebagai adat Mandailing 
Natal, melainkan ini tradisi yang dirubah masyarakat secara bertahap, dulunya pengantin itu melakukan resepsi awal sampai akhir biasanya memakai baju godang, ampu, bobar, bulang, jagar-jagar dan selendang songket, perubahan yang dibuat masyarakat ini menambah jumlah dan macam pakain pengantin. Adapun persepsi masyarakat tentang pakaian pemberangkatan pengantin di Mandailing Natal, yaitu: 1) Tradisi yang dirubah masyarakat Mandailing Natal hanya sebagai doa untuk pengantin baru; 2) Masyarakat Mandailing Natal melambangkan jubah warna putih itu dari kesucian, kebersihan dan kemurnian, pernikahan yang dilambangkan kesucian dan kemurnian ini akan menjadi awal baik untuk pengantin yang akan membina keluarga sakinah mawaddah warahmah yang dipenuhi cinta yang suci, bersih dan murni; 3) Serban yang dipakai pengantin lakilaki adalah salah satu melambangkan kesopanan; dan 4) Mandailing Natal memiliki keistimewaan karena sudah bangga memakai simbol baju persatuan umat Islam. Hal tersebut menandakan pernikahan mereka dibentengi dengan simbol kepercayaan Islam dan iman. Menurut penulis, persepsi masyarakat Mandailing Natal tidaklah melanggar hukum Islam dan kebiasaan yang dilakukan masyarakat ini sangatlah bagus, karena dari persepsi yang telah dipaparkan di atas bukanlah untuk mengkikis adat Mandailing Natal, tapi untuk memajukan nilainilai Islam di dalam masyarakat itu sendiri, yaitu hanya sebagai doa dan kebaikan untuk pengantin baru.

\section{REFERENSI}

Al-Mun'im, A. (1999). Abd al-Mun'im, Mu'jam al-Mustalahat Wa al-Alfaz alFiqhiyyah Juz, 2. Dar al-Fadilah.

Al-Syafi'i, A.-I. T. al-D. A. B. bin M. al-H. al-D. (n.d.). Kifayah Al-Akhyar Fi Halli Ghayat al-Ikhtishar Juz 2. Usaha Keluarga.

Al-Tabrani. (n.d.). al-Mu 'Jam al-Kabir Juz 2. Dar Ihya' al-Turath al-'Arabiy.

Arifin, G. (2018). Fiqih Haji Dan Umrah. PT Gramedia.

Departemen Agama RI. (2009). Al-Qur'an dan Tafsirnya, Jilid 1 (3rd ed.). PT Karya Toha Putra.

Farid, I. (1999). Ibadah haji dalam Filsafat Hukum Islam. In Jakarta: PT. Rineka Cipta. PT. Rineka Cipta.

Hidayat, F., \& Markos, T. (2019). Hadis-Hadis Tentang Isbal: Studi Pemahaman dan Pengamalan di SDIT Dar El-Iman Padang. Istinarah: Riset Keagamaan, Sosial Dan Budaya, 1(1), 54-68.

Ismatulloh, A. M. (2019). Konsep Sakinah, Mawaddah Dan Rahmah Dalam AlQur'an (Prespektif Penafsiran Kitab Al-Qur'an Dan Tafsirnya). Jurnal Artikel Padang, 14(1), 53-64.

Kamal, M. (1974). Asas hukum Islam tentang perkawinan. Bulan Bintang. 
Khusna, A. M. (2018). Hakekat Ritual Ibadah Haji dan Maknanya berdasarkan Pemikiran William R. Roff. An-Nas, 2(1), 132-145.

Lexy, J. M., \& others. (2002). Metodologi Penelitian Kualitatif. In Bandung: Remaja Rosdakarya. Remaja Rosdakarya.

Manan, A. (2017). Aneka masalah hukum perdata Islam di Indonesia. Prenada Media.

Munawwir, A. W. (2002). Al-Munawwir Kamus Arab-Indonesia (XXV). Pustaka Progessif.

Rofiq, A. (1997). Hukum Islam di Indonesia. PT RajaGrafindo Persada.

Rofiq, A. (2000). Ahmad Rofiq, Hukum Islam Di Indosia (IV). PT RajaGrafindo Persada.

Shihab, M. Q. (2002). Pesan, Kesan dan Keserasian Al-Qur'an. In Jakarta: Lentera Hati. Lentera Hati.

Sudarsono. (2005). Hukum Perkawinan Nasional. Rineka Cipta.

Syamsuddin, S. (2007). Metodologi Penelitian Living Qur'an dan Hadis. In Yogyakarta: Teras. Teras. 